\title{
Exploring the relation between parenting style and children's self-concept and subjective and objective metacognition*
}

\author{
Cómo citar este artículo: \\ Gutiérrez de Blume, A.P., Montoya \\ Londoño, D.M., García Gómez, M.E., \\ Osorio Cárdenas, A.M. \& González Benítez, L. \\ (2021). Exploring the relation between \\ parenting style and children's self-concept \\ and subjective and objective metacognition. \\ Revista Latinoamericana de Estudios de \\ Familia, 13(2), 11-37. \\ https://doi.org/10.17151/rlef.2021.13.2.2
}

\author{
Antonio P. Gutiérrez de Blume** \\ Diana Marcela Montoya Londoño*** \\ María Eugenia García Gómez ${ }^{* * * *}$ \\ Andrea Milena Osorio Cárdenas ${ }^{* * * * *}$ \\ Liliana González Benítez ${ }^{* * * * * *}$
}

Recibido: 19 de marzo de 2021 Aprobado: 10 de mayo de 2021

\begin{abstract}
Objective. To examine the relationship between parenting styles (of mothers and fathers), children's self-concept, and subjective and objective measures of metacognition, and to investigate whether self-concept and parenting style predicted metacognition. Methodology. A convenience sample of 196 students who belong to an official educational institution was used; this study implemented a quantitative correlational design. The study also used a series of ordinary least squares (OLS) regression models to examine the extent to which mothers' and fathers' parenting styles as well as children's self-concept predicted children's subjective metacognitive awareness and objective metacognitive monitoring. Results. Parenting styles predicted metacognition in three learning domains (reading comprehension, mathematics, and similarities), although in different ways. Furthermore, children's self-concepts also
\end{abstract}

\footnotetext{
* This article is the result of the research project titled, "Metacognition, self-concept, and parenting style of children in Colombia".

** Georgia Southern University, Statesboro, Georgia, Estados Unidos. E-mail: agutierrez@georgiasouthern.edu.

(D) orcid.org/0000-0001-6809-1728. Google Scholar

*** Universidad de Caldas, Universidad de Manizales. Manizales, Colombia. E-mail: diana.montoya@ucaldas.edu.co.

iD orcid.org/0000-0001-8007-0102. Google Scholar

**** Docente Universidad de Manizales. Rectora Instituto Latinoamericano, Manizales, Colombia.

Email: megarcia@umanizales.edu.co. (D) orcid.org/0000-0001-6538-8411. Google Scholar

***** Universidad Autónoma de Manizales, Secretaria de Educación de Manizales (SEM). Manizales, Colombia.

E-mail: andrea.osorio@autonoma.edu.co. (D) orcid.org/oooo-0oo2-5143-2829. Google Scholar

***** Universidad de Manizales. Manizales, Colombia. E-mail: Igonzalez@umanizales.edu.co.

(iD orcid.org/0000-0002-4998-1271. Google Scholar
}

DOI: 10.17151/rlef.2021.13.2.2. 
predicted metacognition in all three domains. Conclusion. Education must extend beyond school and children to include family. These educational outreach efforts should incorporate more than just how family life affects learning outcomes, such as children's performance in academic domains, but also how family life affects children's metacognitive abilities.

Key words: parenting style; metacognitive awareness; children's self-concept; monitoring accuracy.

\section{Explorando la relación entre los estilos parentales, el autoconcepto y la metacognición subjetiva y objetiva de los niños}

Resumen: Objetivo. Examinar la relación entre los estilos parentales (de madres y padres), el autoconcepto de los niños y las medidas subjetivas y objetivas de metacognición, e investigar si el autoconcepto y el estilo parental predijeron la metacognición. Metodología. Diseño correlacional cuantitativo en el que se trabajo con una muestra por conveniencia de 196 estudiantes pertenecientes a una institución educativa de carácter oficial. Empleando una serie de modelos de regresión de mínimos cuadrados ordinarios (MCO), el estudio examinó hasta qué punto los estilos parentales de la madre y el padre, así como el autoconcepto de los niños, predijeron la conciencia metacognitiva subjetiva y el monitoreo metacognitivo objetivo de los niños. Resultados. Los estilos parentales de los padres y las madres predijeron la metacognición en tres dominios del aprendizaje (comprensión lectora, matemáticas y similitudes), aunque de diferentes maneras. Además, los autoconceptos de los niños también predijeron la metacognición en los tres dominios. Conclusión. La educación de los niños debe extenderse más allá del contexto de la escuela para incluir a la familia. Estos esfuerzos de extensión educativa deben incorporar procesos de intervención en la formación de los niños en los que se considere no sólo cómo la vida familiar afecta los resultados del aprendizaje y el desempeño de los niños en diferentes campos de los dominios académicos, sino también cómo la vida familiar afecta las habilidades metacognitivas durante la infancia.

Palabras clave: estilos parentales; conciencia metacognitiva; autoconcepto de los niños; precisión del monitoreo. 
Exploring the relation between parenting style and children's self-concept and subjective...

\section{Introduction}

Metacognition is recognized as an important process throughout the lifespan. It is generally understood as a higher-order thinking process that involves individuals' ability to monitor and control their own behaviors (Flavell, 1979, 1987). Within a learning context, metacognition is divided into two main processes, knowledge of cognition and regulation of cognition (Schraw and Dennison, 1994). However, metacognition and its associated skills need to be developed, modeled, and scaffolded from early in life, and hence, the role of the family, especially parents, is essential (Whitebread and Neale, 2020).

The development of metacognition in children seems to require not only explicit strategic instruction (Gutiérrez de Blume, 2017; Huff and Nietfeld, 2009), but also family socialization that favors their empowerment and development because social and cultural factors have a significant impact on the metacognitive development of children (Downing et al., 2007). Traditionally, metacognition has been studied as a knowledge problem that is expressed in the development and learning experiences of people individually (Brown, 1987; Flavell, 1979, 1987). Theoretical accounts have conceptualized metacognition as a higher order process in which an object level and a target level interact and help explain the reciprocal relation between monitoring and control processes experienced by individuals around their own cognitive and learning activity (Nelson and Narens, 1990). However, the importance of research on the modeling of metacognitive strategies by parents and teachers has recently begun to be considered in the metacognitive development during early childhood (Whitebread and Neale, 2020).

In this recent approach to metacognition during childhood, the importance of an enriched family environment that favors social interactions quality is recognized in the fact that children can feel capable and confident, and, subsequently, they can develop a healthy concept about themselves as people and as learners. Research shows that students who have family support show better academic performance and have a more positive school attitude insofar as the supportive relationship made by parents seems to influence different socio-emotional behaviors that impact academic results (Rani and Duhan, 2020). Thus, the main purpose of the present study is to explore the extent to which mothers' and fathers' parenting style and children's self-concepts predict their subjective metacognitive awareness and objective measures of metacognitive monitoring. 


\section{Theoretical Considerations}

The study of metacognition during childhood seems to originate with Piaget, as a significant evolution of his work on the development of thought in children, after the postulation of his proposal of functional invariants and variants (Piaget, 1970). In the context of the evolution of his theory, his first formulations on metacognition in childhood emerged from his task of reclassification. In this assessment task, children were required to classify objects into groups according to a chosen criterion and then reclassify them into different groups using a second different criterion (Inhelder and Piaget, 1964).

In this perspective, the development of children's ability to reclassify depended, in turn, on the development of their own ability to have mental flexibility in retrospect and foresight. These two processes should enable children to consider their initial classification criterion while selecting the second criterion, a finding that made different subsequent studies on the ability of children to monitor and report on their own cognitive processes possible (Piaget, 1977, 1978; Whitebread and Neale, 2020). Developmental metacognition studies were strengthened by Flavell's work on the development of a metacognitive monitoring model based on his research on the development of metamemory in children (Flavell, 1979, 1987), and different studies on meta-understanding (Brown, 1978, 1987).

More recent research has included measuring metacognition in children (Sperling et al., 2002), studies on metacognitive judgments during childhood (Van Loon et al., 2013), studies that have explored the trajectories of the development of metacognition (O'Leary and Sloutsky, 2019), and different works of research in which the relationship of metacognition with other cognitive processes, especially with executive functions, has been considered (Follmer and Sperling, 2019; Marulis et al., 2020; Roebers, 2017).

Along the lines of contextual factors that influence children's metacognitive development, the study of parenting styles is based on the approach of the family socialization construct. It is understood as the process by which people internalize the beliefs, values, norms and forms of behavior that are considered appropriate at the social level, a process that develops with special emphasis during childhood (García, 2015). In this context, parental socialization accounts for the influence that parents have on their children in the acquisition of behaviors that society considers appropriate, including behaviors that are related to consideration for others, selfconcept, self-esteem, and the acceptance of responsibilities. Thus, the parenting style of the parents can influence the level of self-regulation or control that children achieve in the face of social norms, including during learning episodes (Martínez et al., 2020).

In general, the studies on parenting styles are based on a two-dimensional model with four basic typologies. These include the authoritarian, negligent, 
Exploring the relation between parenting style and children's self-concept and subjective...

authoritative, and indulgent parenting style, which help explain the behavior of parents in their task to educate children. Thus, when parents act with acceptance / involvement and severity / imposition, they are considered authoritative. If they act with acceptance / implication, but without the component of severity / imposition, they are considered indulgent. If they act with severity / imposition but without acceptance / implication, they are considered authoritarian. Finally, if they act without acceptance / implication and without severity / imposition, they are considered negligent (Musitu and García, 2001). However, for the present study, only three of the four parenting styles were used-authoritarian, indulgent, and negligent. Besides the potential to influence children's metacognition, parenting styles may also exert influence over children's self-concept.

Self-concept has generally been understood as the set of beliefs that people have about themselves, and that derives from their process of social interaction that begins during childhood and that is impacted by family and life at school (García and Musitu, 1999). More specifically, self-concept refers to the perception that people have about themselves at a certain moment, and it is structured based on the set of beliefs developed through a process of permanent self-evaluation of individuals. This perspective is based on a multidimensional self-concept model, for example, academic, social, family, and physical self-concepts (García and Musitu, 1999). In children, academic, social, and family self-concept correlate positively with parental styles of affection, understanding and support, and negatively with coercion, violence, indifference, and neglect (García and Musitu, 1999).

\section{Relation between Parenting Style, Self-Concept, and Metacognition}

Few studies have explored the relationship between parenting styles, selfconcept, and metacognition in child development. Research with 300 young people from a secondary school in India, for example, examined the impact of the family environment on metacognition. The results revealed that the family environment showed a positive impact on the metacognitive skills evaluated. Hence, the relevance of the role of the family to model children's thoughts and beliefs was supported because children who received a nurturing home environment, supportive parental relationships, and positive attitudes from their parents had a better overall performance (Rani and Duhan, 2020). Because behaviors such as cooperation, sociability, kindness, tolerance, and indulgence can influence the development of metacognitive skills that are necessary to improve learning and academic performance at all ages, these parenting styles should be encouraged (Rani and Duhan, 2020).

A second study with 350 high school students from Iran aimed to explore the relationship between parenting styles and academic self-deficiency mediated by metacognitive abilities and perfectionism. Findings showed that, in general, people 
who are aware of their metacognitive strategies can solve the challenges that lie ahead and do not see the need to use the process of personal self-handicap in the face of the challenging situations. Likewise, metacognitive skills contributed to planning and designing the learning process, which facilitate control over individuals' cognitive state and inhibit their belief in self-disability (Edalatjoo et al., 2019).

In the present study, the fact that there is a relationship between parenting styles and the metacognitive abilities of children was recognized. From this antecedent, parenting styles are a foundation by which children can create a positive image of themselves by evaluating their relationships with others. In this way, when parents provide their children independence and responsibility and ask them to decide some of their affairs and do their homework, they will be more responsible, autonomous, and independent people in the future. Therefore, the father or mother, who does not have the necessary authority and constantly uses corporal punishment while their follow-up is weak, can prevent their children from using their metacognitive abilities appropriately (Edalatjoo et al., 2019). Thus, the purpose of this study was to explore the relationship between parenting style, self-concept, and subjective and objective metacognition in a sample of children from a central region of Colombia.

\section{The Present Study}

Recent studies have begun to postulate the influence of general and long-term parenting actions known as parenting styles, and children's self-concept on the development of metacognitive abilities. In this perspective, different researchers have argued that intersubjectivity and the shared social experience of the world such as when a parent and their child read a story, make a puzzle, or make a model together, are factors that contribute to metacognitive development. Thanks to children's exposure to social representations of goals and mental states, for instance, they learn to represent those same states internally. In fact, many studies on metacognition during childhood indicate that social interaction represents an important mediator in the development of metacognitive skills (Brinck and Liljenfors, 2013; Dignath et al., 2008; Whitebread and Neale, 2020). Thus, the present study was guided by the following research questions.

\section{Research Questions and Hypotheses}

1. What is the relation between parenting styles and children's self-concept and subjective and objective measures of metacognition?

2. What is the predictive effect of parenting styles (mother and father) on children's subjective metacognitive awareness (knowledge of cognition and regulation of cognition) and objective metacognitive monitoring accuracy in similarity, math, and reading tasks? 
Exploring the relation between parenting style and children's self-concept and subjective...

3. What is the predictive effect of children's self-concept on their subjective metacognitive awareness (knowledge of cognition and regulation of cognition) and objective metacognitive monitoring accuracy in similarity, math, and reading tasks?

Hypothesis 1: parenting styles and children's self-concept and their subjective metacognitive awareness and objective metacognitive monitoring accuracy are expected to be related in the expected theoretical direction. More specifically, the authoritarian and negligent parenting styles were expected to correlate negatively with other variables, whereas the indulgent parenting style was expected to relate positively to other variables. Further, children's self-concept was expected to be positively related to other variables. Hypothesis 2: parenting style would significantly predict children's subjective metacognitive awareness and objective metacognitive monitoring accuracy. Specifically, the authoritarian and negligent parenting styles were expected to negatively predict both subjective metacognitive awareness and objective measures of monitoring accuracy. In contrast, the indulgent parenting style was expected to positively predict these metacognitive variables. Finally, mothers' parenting style was expected to contribute greater predictive power than fathers' parenting style.

- Hypothesis 3: children's self-concept was expected to positively predict both subjective metacognitive awareness and objective monitoring accuracy.

\section{Method}

\section{Participants, Sampling, and Research Design}

The present study used a convenience sampling approach to recruit participants in a non-experimental correlational research design. The sample included 196 children from a mid-sized public school in Colombia. One hundred-five participants were female and 91 were male. Participants' ages ranged from 6 to 17 years $(M=11.99 ; M e d .=11 ; S D=1.09)$. The sample of children in the present study belonged to social strata 1 and 2, which correspond to the most vulnerable sectors at a social level. The families to which the children of the institution belong mostly have blue-collar jobs with an average salary that does not exceed $\$ 257$ monetary units per month in salary scales worldwide. 


\section{Materials and Instruments}

Following is a list of the measures used in the present study. Internal consistency reliability coefficients, Cronbach's alpha, for each self-report scale are presented in Table 1.

\section{Parenting Styles}

The Scale of Parental Socialization in Adolescence (ESPA29), originally validated in Spanish by Musitu and García (2001), was used to measure parenting styles. The ESPA29 is a self-report measure that includes 29 scenarios in which children must respond by reporting how their parents treat them based on each of the scenarios (e.g., shows affection, hits me, is indifferent, talks to me, etc.). The survey contains 13 negative and 16 positive scenarios. These negative and positive scenarios were later used to calculate the scales that make up each parenting style: authoritarian, authoritative, negligent, and indulgent (Musitu and García, 2001).

The authoritative style (high acceptance/involvement and high coercion/ imposition) represents those parents who strive to direct the activities of their children, but in a rational and process-oriented way, stimulate dialogue, and share with the child the reasoning that underlies decisions. In this way, they exercise firm control, but using dialogue. In turn, the indulgent style (high acceptance/ involvement and low coercion/imposition) represents parents who attempt to behave in an affectionate way, accepting the impulses, desires, and actions of their children. They consult with them on household decisions and provide them with explanations of family rules. They allow their children to regulate their own activities as much as possible, helping them with explanations and reasoning, but they avoid coercive control (Musitu and García, 2004).

The authoritarian style (low acceptance/involvement and high coercion/ imposition), on the other hand, refers to the type of parents who try to model, control, and evaluate the behavior and attitudes of the child according to a set of behavioral norms. Therefore, they value obedience as a virtue and favor punitive and forceful measures to bend the will or stubbornness when the child's actions are not considered appropriate behaviors. Finally, the negligent style (low acceptance/ involvement and low coercion/imposition) characterizes parents who have serious difficulties in relating and interacting with their children, and, in defining the limits in their relationship with them, they are parents who have few expressions of affection and deprive their children of fundamental psychological needs such as support and supervision (Musitu and García, 2004).

The analysis of parenting styles was performed separately for the parenting style of the father and the mother, respectively. However, for the purposes of the present 
Exploring the relation between parenting style and children's self-concept and subjective...

study, only three of the parenting styles: authoritarian, indulgent, and negligent were considered to limit the number of analyses involved in the study, and thus, mitigate Type I error rate inflation.

\section{Children's Self-Concept}

Children's self-concept was measured using the Five-Factor Self-Concept Scale (AF5) initially validated by García and Musitu (1999) in Spanish. The AF5 for children is a 31-item scale that measures four subscales related to self-concept: academic (11 items); social (5 items); emotional (9 items); and familial (6 items) (García and Musitu, 1999).

The academic self-concept refers to the perception that children have about the quality of their role as students and the specific qualities that can be valued in the context (e.g., being smart, valued, being a good student). The social self-concept refers to the perception that children have about their social relationships. It refers to children's social network and the difficulty or ease that they exert to maintain and expand it. Likewise, it refers to some qualities that are considered important in interpersonal relationships (e.g., being friendly and cheerful) (García and Musitu, 1999, 2009, 2014).

The emotional self-concept, in turn, implies the perception that children have about their emotional state and their responses to specific situations, with a certain degree of commitment and involvement in their daily life. In this way, it is related to the general perception that children have about their emotional state (e.g., I am nervous, I am easily scared) and their perception of their own emotional state in more specific situations (e.g., when someone talks to me) in which the other person involved in social interaction has a higher rank (e.g., the teacher).

Finally, the familial self-concept refers to the perception that children have of their involvement, participation, and integration in the family environment. This dimension of self-concept is related to two axes. The first one refers to the perception children have of their parents in two important domains of family relationships, such as trust and affection. The second one refers to the family and home with positive and negative feelings that imply beliefs such as, "I feel happy and my family would help me" (feelings of happiness and support), or beliefs such as, "My family is disappointed and I am heavily criticized (which refers to not being involved and not being accepted by other family members) (García and Musitu, 1999, 2009, 2014).

Participants responded on a continuous scale of 0-100 with two qualitative anchors at each end, where 0 represents "not at all true for me" and 100 represents "completely true for me". The items that belonged to each scale were then averaged to calculate each of the four composite self-concept scores. 


\section{Subjective Metacognitive Awareness}

Subjective metacognitive awareness was measured using the youth-version of the Metacognitive Awareness Inventory (MAI Jr.) (Sperling et al., 2002). The MAI Jr. was developed and validated from the original MAI developed by Schraw and Dennison (1994) in English intended for adult samples.

In this work of research, the 18-item version of the MAI Jr. (version B) was used (Sperling et al., 2002). This included the two dimensions of metacognition proposed in the original and classic version of the MAI, knowledge of cognition (9 items) and regulation of cognition (9 items) (Schraw and Dennison, 1994; Sperling et al.,2002). Children were asked to respond to each item on a 5-point scale: $0=$ Never, 1 = Rarely, 2 = Sometimes, 3 = Often, 4 = Always. Since previous applications of the instrument in English-language research, a Flesch-Kincaid grade-level readability score of 4.7 has been reported for the same form of the instrument in the application with children, indicating that it can be easily understood by 5 th grade students with an average age of 10 years old (Ning, 2019).

Scores were calculated by taking the mean of the items that make up each scale, respectively. Next, the combination of declarative, procedural, and conditional knowledge measures was used to calculate the knowledge of cognition scale and the regulation of cognition scale was composed of the combination of planning, monitoring and evaluation of learning items.

\section{Objective Metacognitive Monitoring Accuracy}

Objective metacognitive monitoring was measured by calculating the absolute difference between the confidence of the participants in their performance judgments and their actual performance in three psychometric tasks that were adapted with the permission of the authors of the Infant Neuropsychological Assessment Battery (ENI) (Rosselli et al., 2004). In this sense, a minor adjustment was made to the classic form of the tasks to measure the level of confidence, monitoring accuracy, and performance in each of the tasks.

After each item of each respective task, students were asked to rate their confidence regarding their performance in each item on a $0-100$ scale in which 0 represented a total lack of confidence in the performance on that item and 100 represented total confidence in that performance on the item in question. Subsequently, participants' confidence ratings were averaged across all items in each task. This composite confidence rating was then compared to participants' actual performance on each task to compute absolute monitoring accuracy via the residual score approach. Thus, a 0 score on this variable corresponded to perfect accuracy whereas a higher non-zero score corresponded to lower monitoring accuracy because 
Exploring the relation between parenting style and children's self-concept and subjective...

the difference between confidence and performance was greater (e.g., 75-75 $=0$ would indicate perfect accuracy whereas 75-60 = 15 indicates miscalibration, with higher values indicating poorer monitoring accuracy).

\section{Procedure}

Within the framework of the academic cooperation agreement that the school in which the study was conducted has with the University of Manizales, a first contact was established with the institution to obtain permission to conduct the study. Once the proper authorizations were obtained, the database of the students was consulted, and from there, communication was established with the children's families to extend the invitation to participate in the research. The objectives of the study were presented to parents and they were asked to voluntarily sign the parent permission form to authorize their children to participate in the study.

Subsequently, school administration organized the logistics for the administration of the data-collection instruments with the children in the higher grades of elementary school and first grades of middle school. The administration of the instruments was done by school personnel with training in psychometric and pedagogical tasks, and, given the quarantine conditions typical of the global pandemic derived from the SARS-Cov-2 virus, the completion of the protocol in its entirety was conducted virtually through the Qualtrics platform.

\section{Data Analysis}

Data were first screened for univariate outliers and tested for requisite statistical assumptions prior to data analysis. No extreme outliers were detected in the data, and hence, all 196 complete cases were retained for data analysis. Failure to account for outliers in data analyses subjects the data to potential biases because of the undue influence these atypical scores exert on measures of central tendency and dispersion in inferential statistics (Tabachnick and Fidell, 2013). Data met all requisite statistical assumptions, including linearity, homoscedasticity, univariate normality, and lack of collinearity, and thus, analyses proceeded without making any statistical adjustments to the data. The first research question was answered by conducting a bivariate (zero-order) correlation analysis.

The second research question was answered by conducting a series of hierarchical linear regressions. In each of the hierarchical regressions for the second research question, the mothers' parenting style variables (authoritarian, indulgent, and negligent) were entered as Block 1 predictors and the fathers' parenting style variables (authoritarian, indulgent, and negligent) were entered as Block 2 predictors. 
Composite knowledge of cognition, regulation of cognition, and absolute monitoring accuracy served as the criterion in each regression analysis, respectively.

The third research question was answered by conducting a series of ordinary least squares (OLS; standard/simultaneous) regressions. In each of the standard regressions for the third research question, children's self-concept variables (academic, social, emotional, and familial) served as predictors and composite knowledge of cognition, regulation of cognition, and absolute monitoring accuracy served as the criterion in each regression analysis, respectively. The Bonferroni adjustment to statistical significance was applied to control for familywise Type I error rate inflation.

The squared multiple correlation coefficient $R^{2}$, served as the measure of practical significance, or effect size estimate of the findings. Cohen (1988) provided the following interpretive guidelines for the effect size, $R^{2}: .010-.499$ as small; $.500-.799$ as medium, and $\geq .800$ as large.

\section{Results}

Table 1 shows the descriptive statistics and internal consistency reliability coefficients for all self-report measures. Table 2 shows the bivariate correlation matrices for the metacognitive variables and children's self-concept, and mothers' and fathers' parenting styles .

Table 1. Descriptive Statistics and Internal Consistency Reliability Coefficients for Subjective Metacognitive Awareness, Objective Monitoring Accuracy, Self-Concept, and Parenting Style

\begin{tabular}{lccc}
\hline Variables & $M$ & $S D$ & $\alpha$ \\
\hline Subjective Metacognitive Awareness & & & .87 \\
$\quad$ Knowledge of Cognition & 71.21 & 19.44 & .89 \\
Regulation of Cognition & 66.35 & 21.52 & \\
Objective Absolute Monitoring Accuracy & & & - \\
Reading Comprehension & 10.61 & 9.21 & - \\
Math & 18.77 & 9.38 & - \\
Similarities & 13.83 & 9.47 & .88 \\
Self-Concept & & & .82 \\
Scademic & 59.85 & 15.19 & .85 \\
Emotial & 74.51 & 23.12 & .79 \\
Familial & 61.54 & 18.89 & \\
\hline
\end{tabular}


Exploring the relation between parenting style and children's self-concept and subjective...

\begin{tabular}{lccc}
\hline Variables & $M$ & $S D$ & $\alpha$ \\
\hline Mothers' Parenting Style & & & \\
Authoritarian & 43.25 & 16.30 & .92 \\
Indulgent & 75.42 & 18.44 & .83 \\
Negligent & 18.75 & 4.39 & .85 \\
\hline Fathers' Parenting Style & & & \\
Authoritarian & 51.33 & 10.40 & .80 \\
Indulgent & 71.38 & 24.42 & .95 \\
Negligent & 29.78 & 7.06 & .84 \\
\hline
\end{tabular}

$N=196$

Source: Own elaboration.

Table 2. Zero-Order Correlation Matrix of Subjective Metacognitive Awareness, Objective Metacognitive Monitoring Accuracy, and Mothers'/Fathers' Parenting Style

\begin{tabular}{|c|c|c|c|c|c|c|c|c|c|c|c|c|}
\hline Variable & 1 & 2 & 3 & 4 & 5 & 6 & 7 & 8 & 9 & 10 & 11 & 12 \\
\hline 1. Knowledge a & - & $.79 * *$ & -.10 & -.11 & -.10 & $.71 * *$ & $.51 * *$ & $.45^{* *}$ & .10 & $-.27^{*}$ & $.74^{* *}$ & $-15^{*}$ \\
\hline 2. Regulation a & $.79 * *$ & - & $-.23^{*}$ & $-.28^{*}$ & $.35^{* *}$ & $.65^{* *}$ & $47^{* *}$ & $34^{* *}$ & .04 & $-.34^{* *}$ & $68 * *$ & $-.25^{*}$ \\
\hline 3. Similarity b & -.10 & $-.23^{*}$ & - & $.28 *$ & $.29^{*}$ & $-.33^{* *}$ & $-.32 * *$ & -.11 & -.10 & $.28 *$ & $-.31 *$ & $.25^{*}$ \\
\hline 4. Math b & -.11 & $-.28^{*}$ & $.28^{*}$ & - & $.28 *$ & -.13 & -.16 & -.17 & -.09 & $.33^{* *}$ & $-.28 *$ & $.29^{*}$ \\
\hline 5. Reading b & -.10 & $.35^{* *}$ & $.29^{*}$ & $.28 *$ & - & $-.22 *$ & $-.23^{*}$ & -.08 & $.20^{*}$ & $.29^{*}$ & $-.37 * *$ & $.25^{*}$ \\
\hline 6. Academic c & $.71 * *$ & $.65^{* *}$ & $-.33^{* *}$ & -.13 & $-.22 *$ & - & $.68 * *$ & $.57^{* *}$ & $.31 * *$ & $-.55^{* *}$ & $.77^{* *}$ & $-.33^{* *}$ \\
\hline 7. Social c & $.51^{* *}$ & $.47^{* *}$ & $-.32 * *$ & -.16 & $-.23^{*}$ & $.68 * *$ & - & $.28^{*}$ & $.20^{*}$ & $-.27^{*}$ & $.75^{* *}$ & $-.30 * *$ \\
\hline 8. Emotional c & $.45^{* *}$ & $.34 * *$ & -.11 & -.17 & -.08 & $.57^{* *}$ & $.28 *$ & - & $.49^{* *}$ & $-.47^{* *}$ & $.42^{* *}$ & $-.34^{* *}$ \\
\hline 9. Familial c & .10 & .04 & -.10 & -.09 & $.20 *$ & $\cdot 31 * *$ & $.20 *$ & $.49^{* *}$ & - & $-.57^{* *}$ & $.31 * *$ & $-.61 * *$ \\
\hline 10. Authoritarian d & $-.21 *$ & $-.27^{*}$ & $.22 *$ & .16 & .19 & $-.43^{* *}$ & $-.36 * *$ & $-.40 * *$ & $-46 * *$ & - & $-.49^{* *}$ & $.55^{* *}$ \\
\hline 11. Indulgent d & $.67^{* *}$ & $.56 * *$ & $-.23^{*}$ & -.18 & $-.26 *$ & $.56 * *$ & $.67^{* *}$ & $.30 * *$ & $.32 * *$ & $-.49 * *$ & - & $-.52 * *$ \\
\hline 12. Negligent d & -.11 & $-.22 *$ & $.22^{*}$ & $.23^{*}$ & $.21 *$ & $-.23 *$ & $-.21 *$ & $-.32 * *$ & $-.54^{* *}$ & $.56 * *$ & $-.32 * *$ & \\
\hline
\end{tabular}

Note. Correlations above the diagonal are for mothers' parenting style and those below the diagonal are for fathers' parenting style.

Key: a Subjective metacognitive awareness scales; b Objective metacognitive monitoring accuracy; c Self-concept; d Parenting style.

$N=196$

Source: Own elaboration. 


\section{Relation between Parenting Style, Children's Self-Concept, and Metacognition}

Regarding the answer to the first research question, mothers' parenting style was more highly related to other variables of interest to the present study than fathers' parenting style. Across the board, the authoritarian and negligent parenting styles were negatively related to children's self-concept and subjective metacognitive awareness variables and were associated with decreased objective metacognitive monitoring accuracy across the three academic domains. Conversely, the indulgent parenting style was positively related to children's self-concept and subjective metacognitive awareness variables and it was associated with increased objective metacognitive monitoring accuracy across academic domains. Subjective metacognitive awareness, both knowledge of cognition and regulation of cognition, were more highly related to parenting style than objective measures of metacognitive monitoring accuracy, and this relation was the strongest for the indulgent parenting style, albeit it was more highly related to the mothers' parenting style. Children's self-concept was more highly related to subjective metacognitive awareness than objective metacognitive monitoring accuracy. Interestingly, children's academic self-concept was generally more highly related to subjective and objective measures of metacognition, albeit no significant relation emerged between any aspects of children's self-concept and objective metacognitive monitoring accuracy in math. Finally, subjective regulation of cognition was more highly related to objective metacognitive monitoring accuracy across domains than subjective knowledge of cognition.

\section{Predictive Effect of Parenting Style on Metacognition}

Some interesting patterns emerged regarding the predictive effect of parenting style on subjective and objective measures of metacognition. Table 3 contains the hierarchical linear regression results, including the regression coefficients for each parenting style (mothers' and fathers') with the Bonferroni adjustment to statistical significance controlling for the number of regression models.

The omnibus model with children's subjective knowledge of cognition was statistically significant, $F(6,190)=50.91, p<.001, R^{2}=.62$. Mothers' parenting style contributed significant incremental variance to the prediction of children's subjective knowledge of cognition, $\Delta F(3,193)=86.46, \Delta p<.001, \Delta R^{2}=.57$. Fathers' parenting style also contributed significant incremental variance to the prediction of children's subjective knowledge of cognition, $\Delta F(3,190)=7.13, \Delta p<.001, \Delta R^{2}=.05$, albeit to a lesser extent than the mothers' parenting style. In this model, the mothers' and fathers' indulgent parenting style predicted an increase in children's self-report knowledge of cognition, albeit the mothers' indulgent style was the best predictor. In contrast, only 
Exploring the relation between parenting style and children's self-concept and subjective...

the fathers' authoritarian style contributed to a reduction in children's self-report knowledge of cognition.

The omnibus model with children's subjective regulation of cognition was statistically significant, $F(6,190)=56.42, p<.001, R^{2}=.64$. Mothers' parenting style contributed significant incremental variance to the prediction of children's subjective regulation of cognition, $\Delta F(3,193)=60.40, \Delta p<.001, \Delta R^{2}=.48$. Fathers' parenting style also contributed significant incremental variance to the prediction of children's subjective knowledge of cognition, $\Delta F(3,190)=27.53, \Delta p<.001, \Delta R^{2}=.16$, albeit to a lesser extent than the mothers' parenting style. Here, both the mothers' and fathers' indulgent parenting style contributed to an increase in children's subjective regulation of cognition, although the mothers' indulgent style was a better predictor. Both parents' authoritarian parenting style negatively predicted children's subjective regulation of cognition, even though the fathers' authoritarian style contributed to a greater reduction in children's subjective regulation of cognition. Finally, only the mothers' negligent parenting style negatively predicted children's subjective regulation of cognition.

The omnibus model with children's objective metacognitive monitoring accuracy in reading comprehension was statistically significant, $F(6,190)=$ $4.72, p<.001, R^{2}=.14$. Mothers' parenting style contributed significant incremental variance to the prediction of children's objective metacognitive monitoring accuracy in reading comprehension, $\Delta F(3,193)=7.65, \Delta p<.001, \Delta R^{2}=.11$. Fathers' parenting style, however, did not contribute significant incremental variance to the prediction of children's objective metacognitive monitoring accuracy in reading comprehension, $\Delta F(3,190)=1.62, \Delta p<.19, \Delta R^{2}=.03$. In this model, only the mothers' parenting style was a significant predictor of children's objective monitoring accuracy in reading comprehension, with the authoritarian and negligent parenting styles contributing to a reduction of monitoring accuracy in reading comprehension whereas the indulgent parenting style being associated with an increase in reading monitoring accuracy.

The omnibus model with children's objective metacognitive monitoring accuracy in math was statistically significant, $F(6,190)=5.83, p<.001, R^{2}=.16$. Mothers'parenting style contributed significant incremental variance to the prediction of children's objective metacognitive monitoring accuracy in math, $\Delta F(3,193)=7.27$, $\Delta p<.001, \Delta R^{2}=.10$. Fathers' parenting style also contributed significant incremental variance to the prediction of children's objective metacognitive monitoring accuracy in math, $\Delta F(3,190)=4.00, \Delta p=.009, \Delta R^{2}=.06$. Interestingly, both parents' negligent style was the only significant predictor of children's objective monitoring accuracy in math, with both contributing to a reduction in children's math monitoring accuracy.

The omnibus model with children's objective metacognitive monitoring accuracy in similarities was statistically significant, $F(6,190)=9.44, p<.001, R^{2}=.24$. Mothers' parenting style contributed significant incremental variance to the 
prediction of children's objective metacognitive monitoring accuracy in similarities, $\Delta F(3,193)=6.70, \Delta p<.001, \Delta R^{2}=.10$. Fathers' parenting style also contributed significant incremental variance to the prediction of children's objective metacognitive monitoring accuracy in similarities, $\Delta F(3,190)=11.12, \Delta p<.001, \Delta R^{2}=.14$. As with the model with math monitoring accuracy, both parents' negligent style significantly predicted children's objective monitoring accuracy in similarities, with both being associated with a reduction in children's similarities accuracy. However, only the mothers' authoritarian parenting style significantly predicted children's objective monitoring accuracy in similarities, contributing to a reduction in accuracy.

Table 3. Hierarchical Linear Regression Results of the Predictive Effects of Parenting Style on Subjective Metacognitive Awareness and Objective Metacognitive Monitoring

\begin{tabular}{|c|c|c|c|c|}
\hline Predictor & $B+[$ S.E. $]\left(\mathrm{Cl}_{95 \%}\right)$ & $\beta-$ & $t$ & $p$ \\
\hline \multicolumn{5}{|c|}{ Subjective Knowledge of Cognition } \\
\hline \multicolumn{5}{|l|}{ Mothers' Parenting Style } \\
\hline Authoritarian & $-.18[.07](-.33,-.04)$ & -.15 & -2.25 & .02 \\
\hline Indulgent & $.86[.05](.75, .98)$ & .82 & 14.70 & $<.001 *$ \\
\hline Negligent & $.04[.08](-.12, .19)$ & .03 & .48 & .63 \\
\hline \multicolumn{5}{|l|}{ Fathers' Parenting Style } \\
\hline Authoritarian & $-.42[.13](-.67,-.16)$ & -.44 & -3.24 & $.001 *$ \\
\hline Indulgent & $.39[.08](.22, .56)$ & .48 & 4.62 & $<.001 *$ \\
\hline Negligent & $.06[.09](-.13, .24)$ & .05 & .62 & .55 \\
\hline \multicolumn{5}{|c|}{ Subjective Regulation of Cognition } \\
\hline \multicolumn{5}{|l|}{ Mothers' Parenting Style } \\
\hline Authoritarian & $-.28[.07](-.47,-.13)$ & -.25 & -3.12 & $.002 *$ \\
\hline Indulgent & $.91[.07](.76,1.05)$ & .78 & 12.67 & $<.001 *$ \\
\hline Negligent & $-.37[.09](-.57,-.18)$ & -.30 & -3.77 & $<.001 *$ \\
\hline \multicolumn{5}{|l|}{ Fathers' Parenting Style } \\
\hline Authoritarian & $-.98[.14](-1.25,-.71)$ & -.93 & -7.14 & $<.001 *$ \\
\hline Indulgent & $.54[.09](.36, .72)$ & .61 & 5.99 & $<.001 *$ \\
\hline Negligent & $-.10[.09](-.29, .09)$ & -.07 & -1.03 & .31 \\
\hline
\end{tabular}


Exploring the relation between parenting style and children's self-concept and subjective...

\begin{tabular}{|c|c|c|c|c|}
\hline Predictor & $B+[\mathrm{S} . \mathrm{E}].\left(\mathrm{Cl}_{95 \%}\right)$ & $\beta-$ & $t$ & $p$ \\
\hline \multicolumn{5}{|c|}{ Objective Monitoring Accuracy in Reading Comprehension } \\
\hline \multicolumn{5}{|l|}{ Mothers' Parenting Style } \\
\hline Authoritarian & $.19[.06](.08, .33)$ & .39 & 3.98 & $<.001 *$ \\
\hline Indulgent & $-.28[.04](-.37,-.15)$ & -.39 & -3.96 & $<.001 *$ \\
\hline Negligent & $.31[.06](.18, .44)$ & .58 & 4.75 & $<.001 *$ \\
\hline \multicolumn{5}{|l|}{ Fathers' Parenting Style } \\
\hline Authoritarian & $.08[.05](-.04, .19)$ & .14 & 1.34 & .18 \\
\hline Indulgent & $-.09[.04](-.17, .01)$ & -17 & -2.00 & .048 \\
\hline Negligent & $.001[.05](-.11, .11)$ & .01 & .01 & 99 \\
\hline \multicolumn{5}{|c|}{ Objective Monitoring Accuracy in Math } \\
\hline \multicolumn{5}{|l|}{ Mothers' Parenting Style } \\
\hline Authoritarian & $.10[.05](-.01, .21)$ & .18 & 1.80 & .07 \\
\hline Indulgent & $.01[.04](-.09, .07)$ & .02 & .22 & .83 \\
\hline Negligent & $.25[.06](.12, .38)$ & .46 & 3.80 & $<.001 *$ \\
\hline \multicolumn{5}{|l|}{ Fathers' Parenting Style } \\
\hline Authoritarian & $.06[.09](-.24, .12)$ & .13 & .64 & .52 \\
\hline Indulgent & $-.12[.06](-.001, .24)$ & -.31 & -1.95 & .05 \\
\hline Negligent & $.18[.06](.07, .30)$ & .28 & 3.26 & $.001 *$ \\
\hline \multicolumn{5}{|c|}{ Objective Monitoring Accuracy in Similarities } \\
\hline \multicolumn{5}{|l|}{ Mothers' Parenting Style } \\
\hline Authoritarian & $.23[.05](.11, .39)$ & .29 & 3.02 & $.004^{*}$ \\
\hline Indulgent & $-.08[.04](-.001, .16)$ & -.15 & -1.96 & .05 \\
\hline Negligent & $.24[.05](.12, .38)$ & .28 & 3.01 & $.004^{*}$ \\
\hline \multicolumn{5}{|l|}{ Fathers' Parenting Style } \\
\hline Authoritarian & $-.02[.08](-.19, .15)$ & -.05 & -.30 & .83 \\
\hline Indulgent & $.01[.06](-.13, .10)$ & .03 & .21 & .84 \\
\hline Negligent & $.36[.06](.23, .48)$ & .64 & 5.56 & $<.001 *$ \\
\hline
\end{tabular}

$N=196{ }^{*} p \leq .01$

$B+=$ Unstandardized regression coefficients and their $95 \%$ confidence interval $\left(\mathrm{CI}_{95 \%}\right)$.

S.E. $=$ Standard error for the unstandardized regression coefficients.

$\beta-=$ Standardized regression coefficients.

Source: Own elaboration. 


\section{Predictive Effect of Children's Self-Concept on Metacognition}

Unique patterns also emerged regarding the predictive effect of children's selfconcept on subjective and objective measures of metacognition. Table 4 contains the standard/simultaneous linear regression results, including the regression coefficients for each aspect of self-concept with the Bonferroni adjustment to statistical significance controlling for the number of regression models.

The omnibus model with children's subjective knowledge of cognition was statistically significant, $F(4,192)=60.00, p<.001, R^{2}=.56$. However, only the academic and familial aspects of children's self-concept significantly predicted their subjective knowledge of cognition, the former positively and the latter negatively.

The omnibus model with children's subjective regulation of cognition was statistically significant, $F(4,192)=50.22, p<.001, R^{2}=.49$. However, as with the previous model, only the academic and familial aspects of children's self-concept significantly predicted their subjective regulation of cognition, the former positively and the latter negatively.

The omnibus model with children's objective monitoring accuracy in reading comprehension was statistically significant, $F(4,192)=14.69, p<.001, R^{2}=.25$. However, only the academic, social, and emotional aspects of children's self-concept significantly predicted their objective reading comprehension monitoring accuracy. The academic aspect contributed to an increase in reading comprehension accuracy whereas the social and emotional aspect were associated with a decrease in accuracy.

The omnibus model with children's objective monitoring accuracy in math did not reach statistical significance, $p=.53$, as no predictor was significant.

The omnibus model with children's objective monitoring accuracy in similarities was statistically significant, $F(4,192)=15.16, p<.001, R^{2}=.24$. However, only the academic and emotional aspects of children's self-concept significantly predicted their objective similarities monitoring accuracy. Both aspects contributed to an increase in similarities monitoring accuracy. 
Exploring the relation between parenting style and children's self-concept and subjective...

Table 4. Simultaneous Regression Results of the Predictive Effects of Children's Self-Concept on Subjective Metacognitive Awareness and Objective Metacognitive Monitoring

\begin{tabular}{|c|c|c|c|c|}
\hline Predictor & $B+[\mathrm{S} . \mathrm{E}].\left(\mathrm{Cl}_{5} \%\right)$ & $\beta-$ & $t$ & $p$ \\
\hline \multicolumn{5}{|c|}{ Subjective Knowledge of Cognition } \\
\hline Academic & $.88[.10](.68,1.07)$ & .69 & 8.82 & $<.001 *$ \\
\hline Social & $.02[.05](-.09, .13)$ & .02 & .32 & .75 \\
\hline Emotional & $.15[.06](.02, .280$ & .15 & 2.30 & .02 \\
\hline Familial & $-.24[.07](-.37,-.10)$ & -.19 & -3.38 & $.001 *$ \\
\hline \multicolumn{5}{|c|}{ Subjective Regulation of Cognition } \\
\hline Academic & $.95[.12](.71,1.19)$ & .67 & 7.80 & $<.001 *$ \\
\hline Social & $.02[.07](-.12, .15)$ & .02 & .28 & .78 \\
\hline Emotional & $.06[.08](-.10, .22)$ & .05 & 69 & .49 \\
\hline Familial & $-.28[.08](-.45,-.11)$ & -.20 & -3.24 & $.001 *$ \\
\hline \multicolumn{5}{|c|}{ Objective Monitoring Accuracy in Reading Comprehension } \\
\hline Academic & $-.36[.06](-.48,-.23)$ & -.59 & -5.71 & $<.001 *$ \\
\hline Social & $.22[.04](.15, .29)$ & .54 & 6.09 & $<.001 *$ \\
\hline Emotional & $.17[.04](.09, .25)$ & .35 & 4.13 & $<.001 *$ \\
\hline Familial & $-.11[.04](-.19,-.02)$ & -.18 & -2.43 & .02 \\
\hline \multicolumn{5}{|c|}{ Objective Monitoring Accuracy in Math } \\
\hline Academic & $.06[.07](-.08, .20)$ & .10 & .86 & .39 \\
\hline Social & $-.04[.04](-.12, .04)$ & -.11 & -1.07 & .29 \\
\hline Emotional & $-.03[.05](-.13, .06)$ & -.07 & -.69 & .49 \\
\hline Familial & $-.05[.05](-.15, .05)$ & -.08 & -.98 & .33 \\
\hline
\end{tabular}

Objective Monitoring Accuracy in Similarities

\begin{tabular}{lcccc}
\hline Academic & $-.30[.06](-.43,-.18)$ & -.49 & -4.83 & $<.001^{*}$ \\
Social & $.04[.04](-.03, .11)$ & .10 & 1.18 & .24 \\
Emotional & $-19[.04](-.27,-.10)$ & -.37 & -4.40 & $<.001^{*}$ \\
Familial & $-.05[.04](-.14, .04)$ & -.08 & -1.09 & .27 \\
\hline
\end{tabular}

$N=196{ }^{*} p \leq .01$

$B+=$ Unstandardized regression coefficients and their $95 \%$ confidence interval $\left(\mathrm{CI}_{95 \%}\right)$.

S.E. $=$ Standard error for the unstandardized regression coefficients.

$\beta$ - = Standardized regression coefficients.

Source: Own elaboration. 


\section{Discussion}

This work of research adopts the view for a metacognitive capacity that is present in children from an early age, based on the idea of a theory of mind that allows them to have metacognitive behaviors during early childhood (Flavell, 1999; Kuhn, 2000; Shatz, Wellman and Silber, 1983). In this sense, the importance of not only instruction at the teaching level for their development and evolution is recognized, but also the different social interactions at the family level that can contribute to enhancing or limiting the development of the child's metacognitive capacity, including their possibilities for adequate school performance. Some researchers, for example, have shown that early social interactions in the family and in the educational institution, which explicitly model the use of metacognitive knowledge to inform strategic choices, can significantly impact the development of children's academic skills (Perry, 1998; Whitebread, 2014; Whitebread et al., 2015). In other words, the impact of the support practices that children find in their family and school environment can contribute to the development of their metacognitive capacity, as this type of social interactions can be a scenario for children to make autonomous decisions and increasing their awareness that allow them to reflect on their own learning.

The results of this research showed the multiple and complex relationships between the different variables evaluated. More specifically, parenting styles and self-concept represent two psychological constructs that have a predictive effect on the metacognitive skills of children. In this sense, family socialization and social interaction processes have effects on the personality and on the adjustment of the child and adolescent insofar as they determine the limits of the behaviors that are considered adequate and desirable in each culture. Some researchers have defined socialization as a non-formalized process in which, through social interactions, the child assimilates knowledge, attitudes, values, customs, needs, feelings, and other cultural patterns that characterize for life his style of adaptation to the context and social environment, including the school context (Martínez et al., 2003; Musitu and Allatt, 1994).

The paternal filial socialization styles suppose, on the one hand, parental socialization as an integrated part of the process of immersion in the society to which one belongs. In addition, it leads to the fulfillment of objectives related to teaching the child aspects such as impulse control (including the development of awareness and capacity to self-regulate), the preparation and execution of the role (includes gender and institutional roles), and the cultivation of sources of meaning (which involves learning about the valuation of those that is considered important at the social level, and why to do it). 
Exploring the relation between parenting style and children's self-concept and subjective...

In the present study, authoritarian and negligent parenting styles were negatively related to children's self-concept and subjective metacognitive awareness and were associated with a lower accuracy of objective metacognitive monitoring in the three academic domains. In contrast, the indulgent parenting style was positively related to children's self-concept and subjective metacognitive awareness, and it was associated with greater accuracy in objective metacognitive monitoring across all academic domains. These results are consistent with different studies that have reported that children who were raised in a cooperative and supportive environment performed better in their academic process than children who were raised in a harsh, strict, punishing, and negligent environment (Changalwa et al., 2012; Paulson et al.,1998). In general, negative effects have been reported in children and adolescents who have been educated in authoritarian homes. These children, for example, suffer high coercion / imposition, with the additional problem that represents the low acceptance / involvement that does not suffice to cushion the negative effects of the parenting process that leads these children to show resentment towards their parents and a lower family self-acceptance (Musitu and García, 2004).

Similarly, results of the present study coincide with different studies that demonstrate that the negligent parenting style generates negative effects on children, as it leads them to behave impulsively and become involved early in conflictive behaviors. More specifically, these children manifest a poor orientation to goals and, in general, to schoolwork and a low concept about their own personal capacity. Thus, children who have been educated under this parenting style have poor academic involvement, and lower school performance indicators, because, in addition their academic difficulties, they are usually involved in behavior problems (Karavasilis et al., 2003; Musitu and García, 2004; Steinberg et al.,1994).

The results of the present study coincide with research that found that an indulgent parenting style is related to children who have internalized social norms well, and are especially oriented towards social values, including the value of studying (Musitu and García, 2004). This result may have important implications in the development of metacognition in that it would allow the development of a higher level of confidence and personal security in oneself and in one's own capacity.

Findings also support the conclusion that the indulgent parenting style of mothers and fathers predicted an increase in the knowledge and regulation of selfreport cognition of children, albeit the indulgent style of mothers was the best predictor. This result is consistent with studies that have reported that students with parents who demonstrated an indulgent parenting style generally tend to develop a greater repertoire of cognitive and metacognitive strategies than those with authoritarian and negligent parents (Erden and Uredi, 2008). Likewise, findings are congruent with previous studies which indicate that the indulgent style of parents is related to a more adaptive school adjustment from early childhood to adolescence, 
evincing the importance of parental practices related to a high acceptance/high involvement for adequate school adjustment (Fuentes et al., 2019).

The authoritarian style of parents contributed to a reduction in children's selfreported knowledge of cognition. It also negatively predicted children's subjective regulation of cognition, and it contributed to a greater reduction in children's subjective regulation of cognition compared to subjective knowledge of cognition. Finally, only the negligent parenting style of mothers negatively predicted children's subjective regulation of cognition. These results coincide with studies that demonstrate that the authoritarian and negligent parenting styles have a negative impact on the cognitive and metacognitive processes involved in children's self-regulation of learning, especially in the case of the negligent style (Alnafea and Curtis, 2017; Huang and Prochner, 2003; Nwosu et al., 2016). These studies converge on the finding that the negligent parenting style leads to significant decrements in self-efficacy and metacognitive self-regulation and in the rise in anxiety before academic tasks. Nevertheless, some studies have reported that an authoritarian parenting style may be correlated with self-efficacy, cognitive and metacognitive strategies, and critical thinking in learning settings (Nwosu et al., 2016; Seroussi and Yaffe, 2020).

\section{Implications and Avenues for Future Research}

The present study demonstrated that parenting style has a significant influence not only on children's self-concept, but in both subjective and objective measures of metacognition. Thus, it is paramount that parents be educated regarding the impact their method of parenting has on behaviors both within and beyond home, such as the academic setting. If parents are taught the significance of nurturing, supportive modes of parenting such as the indulgent style, they may make long-lasting changes to their interactions with their children, and the earlier in a child's life this can be done, the better. Further, findings support the conclusion that children's self-concepts also have bearing on subjective and objective measures of their metacognition. Thus, in a more holistic fashion, both parents and children can be taught the various ways in which family contextual variables influence children's individual characteristics, which, subsequently, influence their behaviors at home, in learning contexts, and in society at large. Nevertheless, the present study did not include any motivational, dispositional, or personality factors, which have been shown to also affect the outcomes of interest to the present study (i.e., metacognition). Thus, future research should incorporate these other variables, perhaps in a mediation model, to examine whether children's self-concepts, motivational/dispositional characteristics (e.g., self-efficacy, autonomy, affect, etc.), and personality mediate the relation between parenting style and subjective and objective measures of metacognition. Such a study would indeed disentangle the complex relations between all these relevant variables. 
Exploring the relation between parenting style and children's self-concept and subjective...

\section{Methodological Reflections and Limitations}

No research is without its limitations. First, the present study used self-report measures for parenting styles and metacognitive awareness rather than more objective measures such as behavior inventories or checklists completed by independent raters other than the participants themselves. The main flaw of self-report measures is that individuals may not always be the most honest or accurate raters of their own perceptions, opinions, or attitudes. Second, the present study used a quantitative descriptive research design, with no complementary qualitative component. Including qualitative data would have benefitted the study by enriching the understanding of the how and why, from a more process-oriented approach. Finally, the study used a non-random, convenience sample of participants, which limits the generalizability of the findings to other samples of the population. Despite these limitations, however, it is necessary to highlight some strengths of the study.

The study based its conclusions on a robust sample size, and thus, it is unlikely that the results reported here are spurious. Moreover, the study occurred in an ecologically-valid setting, and hence, the results are more contextually valid. Thus, despite the limitations, the findings of the present study contribute to a better understanding of the relations between parenting style, children's self-concept, and metacognition.

\section{Conclusion}

Metacognition is recognized as a critical higher-order thinking process that assist individuals to monitor, control, and self-regulate their behavior. In learning situations, this involves marshaling a set of metacognitive skills such as knowing when, how, and why to apply certain strategies depending on task demands (conditional knowledge) and how to monitor comprehension of learning and be able to repair any inconsistency in this learning (debugging). The present study showed that factors beyond the academic setting (e.g., interest on the topic, teacher support, utility value in the learning task, etc.) have a profound influence in not only children's self-concepts, but how both parenting style and self-concepts impact children's subjective (knowledge and regulation of cognition) and objective (monitoring) metacognition. Thus, education needs to extend beyond the school and children to include, wherever possible, the family, especially parents. These educational outreach efforts should incorporate more than simply how family life affects learning outcomes such as children's performance in academic domains, but also how family life affects children's metacognitive skills. 


\section{Acknowledgements}

The authors of this article wish to express their sincere gratitude to Mónica Rosselli and Esmeralda Matute for their authorization of the use and adaptation of three subtests of the Infant Neuropsychological Assessment (ENI) that were used as objective psychometric measures for the estimation of objective metacognitive monitoring.

\section{References}

Alnafea, T., \& Curtis, D. (2017). Influence of mothers' parenting styles on self-regulated academic learning among Saudi primary school students. Issues in Educational Research, 27(3), 399-416. http://iier.org.au/iier27/alnafea.pdf

Brinck, I., \& Liljenfors, R. (2013). the developmental origin of metacognition. Infant and Child Development, 22(85), 85-101. https://doi.org/10.1002/icd.1749

Brown, A. (1978). Knowing when, where, and how to remember: A problem of metacognition. In R. Glaser (Ed.), Advances in instructional psychology (pp. 77-165). Erlbaum.

Brown, A. (1987). Metacognition, executive control, self-regulation, and other more mysterious mechanisms. In F. Weinert \& R. Kluwe (Eds.), Metacognition, motivación and understanding (pp. 65-116). Lawrence Erlbaum.

Changalwa, C., Ndurumo, M., Barasa, P., \& Poipoi, M. (2012). The relationship between parenting styles and alcohol abuse among college students in Kenya. Greener Journal of Educational Research, 2(2), 13-20. https://doi.org/10.15580/gjer.2012.2.gjer1210

Cohen, J. (1988). Statistical power analysis for the behavioral sciences (2nd ed.). Lawrence Erlbaum Associates.

Dignath, C., Buettner, G., \& Langfeldt,H. (2008). How can primary school students learn self-regulated learning strategies most effectively?. A meta-analysis on self-regulation training programmes. Educational Research Review, 3(2), 101-129. https://doi.org/10.1016/j.edurev.2008.02.003

Downing, K., Ho, R., Shin, K., Vrijmoed, L., \& Wong, E. (2007). Metacognitive development and moving away. Educational Studies, 33(1), 1-13. https://doi.org/10.1080/03055690600850347

Edalatjoo, A., Mahdian, H., \& Mohammadipour, M. (2019). The relationship between parenting styles and academic self-handicapping through the mediating role of metacognitive and perfectionism skills. Iranian Journal of Educational Sociology, 2(3), 56-66. http://iase-idje.ir/article-1-628-en.pdf

Erden, M., \& Uredi, I. (2008). The effect of perceived parenting styles on self- regulated learning strategies and motivacional beliefs. International Journal about Parents in Education, 2(1), 25-34.

Flavell,J. (1979).Metacognition and Cognitive Monitoring A New Area of Cognitive - Developmental Inquiry. American Psychologist, 34(10), 906-911. https://doi.org/10.1037/0003-066x.34.10.906

Flavell, J. (1987). Speculation about nature and develpment of metacognition. In F. Weinert \& R. Kluwe (Eds.), Metacognition, motivación and understanding (pp. 21-29). Hillsdale. 
Exploring the relation between parenting style and children's self-concept and subjective...

Flavell, J. (1999). Cognitive development: children's knowledge about the mind. Annual Review of Psychology, 50, 21-45. https://doi.org/10.1146/annurev.psych.50.1.21

Follmer, D. J., \& Sperling, R. A. (2019). Examining the role of self-regulated learning microanalysis in the assessment of learners' regulation. Journal of Experimental Education, 87(2). https://doi.org/10 .1080/00220973.2017.1409184

Fuentes, M., García-Ros, R., Pérez-González, F., \& Sancerni, D. (2019). Effects of parenting styles on self-regulated learning and academic stress in Spanish adolescents. International Journal of Environmental Research and Public Health, 16(15), 1-19. https://doi.org/10.3390/ijerph16152778

García, F. (2015). Parenting: cultural influences and impact on childhood health and well- being. Nova Science.

García, F., \& Musitu, G. (1999). AF5: Autoconcepto forma A.TEA.

García, F., \& Musitu, G. (2009). AF5. Autoconcepto forma 5. TEA.

García, F., \& Musitu, G. (2014). Autoconcepto Forma 5. TEA.

Gutiérrez de Blume, A. (2017). The effects of strategy training and an extrinsic incentive on fourthand fifth-grade students' performance, confidence, and calibration accuracy. Congent-Education, 4, 1-17. https://doi.org/10.1080/2331186X.2017.1314652

Huang, J., \& Prochner, L. (2003). Chinese parenting styles and children's self-regulated learning. Journal of Research in Childhood Education, 18(3), 227-238. https://doi.org/10.1080/02568540409595037

Huff, J., \& Nietfeld, J. (2009). Using strategy instruction and confidence judgments to improve metacognitive monitoring. Metacognition and Learning, 4(2), 161-176. https://doi.org/10.1007/ s11409-009-9042-8

Inhelder, B., \& Piaget, J. (1964). The early growth of logic in the child. Routledge.

Karavasilis, L., Doyle, A., \& Markiewicz, D. (2003). Associations between parenting style and attachment to mother in middle childhood and adolescence. International Journal of Behavioral Development, 27(2), 153-164. https://doi.org/10.1080/0165025024400015

Kuhn, D. (2000). Metacognitive development. American Psychological Society, 9(5), 178-181. https://doi. org/10.1111/1467-8721.00088

Martínez-Escudero,J., Villarejo, S., García, O., \& García, F. (2020). Parental socialization and its impact across the lifespan. Behavioral Sciences, 10(6), 1-18. https://doi.org/10.3390/BS10060101

Martínez, I., Musitu, G., Garcia, J., \& Camino, L. (2003). Un análisis intercultural de los efectos de la socialización familiar en el autoconcepto: España y Brasil. Psicologia Educação Cultura, 7(2), 239-259. https://www.uv.es/ garpe/C_/A_/C_A_0022.pdf

Marulis, L.M., Baker, S.T., \& Whitebread, D. (2020). Integrating metacognition and executive function to enhance young children's perception of and agency in their learning. Early Childhood Research Quarterly, 50(1), 46-54. https://doi.org/10.1016/j.ecresq.2018.12.017

Musitu, G., \& Allatt, P. (1994). Psicosociología de la familia. Albatros.

Musitu, G., \& García, F. (2001). Escala de estils de socialización parental en la adolescencia ESPA29. TEA.

Musitu, G., \& García, F. (2004). Escala de estilos de socialización parental en la adolescencia ESPA 29. TEA. 
Antonio P. Gutiérrez de Blume et al.

Nelson, T., \& Narens, L. (1990). Metamemory: a theoretical framework and new findings. In G. Bower (Ed.), The Psychology of Learning and Motivation (pp. 125-173). Academic Press.

Ning, H. (2019). The bifactor model of the junior metacognitive awareness inventory (Jr. MAI). Current Psychology, 38(2), 367-375. https://doi.org/10.1007/s12144-017-9619-3

Nwosu, K., Nwanguma, V., \& Onyebuchi, G. (2016). Parenting styles , test anxiety , and selfefficacy of secondary school students in Nigeria : Lessons from Nigerian sociocultural context. Educational Research Journal, 6, 32-41. https://www.researchgate.net/profile/Kingsley-Nwosu/ publication/296195948_

O'Leary, A., \& Sloutsky, V. (2019). Components of Metacognition Can Function Independently Across Development. Dev Psychol, 55(2), 315-328. https://doi.org/doi:10.1037/dev0000645

Paulson, S., Marchant, G., \& Rothlisberg, B. (1998). Early adolescent's perceptions of patterns of parenting, teaching, and school atmosphere: Implications for achievement. Journal of Early Adolescence, 18(1), 5-26. https://doi.org/10.1177/0272431698018001001

Perry, N. (1998). Young children's self-regulated learning and contexts that support it. Journal of Educational Psychology, 90(4), 715-729. https://doi.org/10.1037/0022-0663.90.4.715

Piaget, J. (1970). L'épistemologie génétique. Presses Universitaires de France.

Piaget, J. (1977). The grasp of consciousness. Routledge.

Piaget, J. (1978). Success and understanding. Routledge.

Rani, M., \& Duhan, K. (2020). Metacognition and Its correlates : a study. International Journal of Home Science, 6(2), 403-409. https://www.homesciencejournal.com/archives/2020/vol6issue2/ PartG/6-2-42-176.pdf

Roebers, C. (2017). Executive function and metacognition: Towards a unifying framework of cognitive self-regulation. Developmental Review, 45, 31-51. https://doi.org/10.1016/j.dr.2017.04.001

Rosselli, M., Matute, E., \& Ardila, A. (2004). Neuropsicología del desarrollo infantil. Manual Moderno.

Schraw, G., \& Dennison, R.S. (1994). Assesing metacognitive awareness. Contemporany Educational Psychology, 19(4), 460-475. https://doi.org/10.1006/ceps.1994.1033

Seroussi, D., \& Yaffe, Y. (2020). Links between israeli college students' self-regulated learning and their recollections of their parents' parenting styles. SAGE Open, 10(1), 1-11. https://doi. org/10.1177/2158244019899096

Shatz, M., Wellman, H., \& Silber, S. (1983). The acquisition of mental verbs: A systematic investigation of the first reference to mental state. Cognition, 14, 301-321. https://doi.org/10.1016/00100277(83)90008-2

Sperling, R. A., Howard, B. C., Miller, L. A., \& Murphy, C. (2002). Measures of children's knowledge and regulation of cognition. Contemporary Educational Psychology, 27(1), 51-79. https://doi. org/10.1006/ceps.2001.1091

Steinberg, L., Lamborn, S., Darling, N., Mounts, N., \& Dornbusch, S. (1994). Over-time changes in adjustment and competence among adolescents from authoritative, authoritarian, indulgent, and neglectful families. Child Development, 65(3), 754-770. https://doi.org/10.1111/j.1467-8624.1994. tb00781.x

Tabachnick, B., \& Fidell, L. (2013). Using multivariate statistics (6th ed.). Pearson. 
Exploring the relation between parenting style and children's self-concept and subjective...

Van Loon, M. H., De Bruin, A. B. H., Van Gog, T. \& Van Merriënboer, J. J. G. (2013). Activation of inaccurate priorknowledge affects primary-school students'metacognitive judgments and calibration. Learning and Instruction, 24(SI), 15-25. https://doi.org/10.1016/j.learninstruc.2012.08.005

Whitebread, D. (2014). The importance of self-regulatio for learning from birth. In H. Moylett (Ed.), Characteristics of effective learning: Helping young children become learners for life (pp. 15-35). Open University Press.

Whitebread, D., \& Neale, D. (2020). Metacognition in early child development. Translational Issues in Psychological Science, 6(1), 8-14. https://doi.org/10.1037/tps0000223

Whitebread, D., Pasternak, D., \& Coltman, P. (2015). Making learning visible: the role of language in the development of metacognition and self-regulation in young children. In S. Robson \& S. Quinn (Eds.), The Routledge international handbook of young children's thinking and understanding (pp. 199-214). Routledge. 